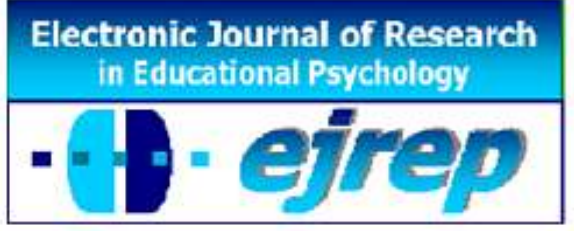

\title{
Predictive Relationship between Humane Values of Adolescents Cyberbullying and Cyberbullying Sensibility
}

\author{
Bülent Dilmaç ${ }^{1}$, Eyüp Yurt ${ }^{2}$, Mustafa Aydın ${ }^{3}$ \\ \& \\ İsmail Kaşarcı ${ }^{4}$
}

${ }^{1}$ Department of Educational Psychology, Necmettin Erbakan University, Konya

${ }^{2}$ Department of Educational Sciences, Gaziantep University, Gaziantep

${ }^{3}$ Department of Curriculum and Instruction, Necmettin Erbakan Univ., Konya

${ }^{3}$ Department of Curriculum and Instruction, Osman Gazi University, Eskişehir

Turkey

Correspondence: Bulent Dilmaç. Necmettin Erbakan University, A. K. Education Faculty, Department of Educational Psychology, Konya-Turkey. e-mail: bulentdilmac@gmail.com

(C) Education \& Psychology I+D+i and Ilustre Colegio Oficial de la Psicología de Andalucía Oriental (Spain) 


\begin{abstract}
Introduction. Cyberbullying has been more common than the traditional bullying in recent years. As with the traditional bullying, humane values likely to explain the reason why adolescents tend to bully via cyber-means. Cyber-bullying behaviors also reasoned by adolescent's sensibility towards it. This study investigates the predictive relationships between humane values of adolescents, cyber-bullying and cyber-bullying sensibility.

Method. The study consisted of a total 1743 participants from different middle schools in Istanbul, Konya, Mersin, Ordu and Bursa (Turkey). 963 of the participants were females and 780 were males. The study group was selected among adolescents studying at the above mentioned secondary schools by a random cluster sampling method. The study employed the "Humane Values Scale," the "Cyberbullying Scale" and the "Cyberbullying Sensibility" scale. Predictive relationships between humane values of adolescents, cyberbullying and cyberbullying sensibility were analyzed with the "Structural Equivalence Model" by using the AMOS 19 computer program.

Results. Results of the study revealed that each of the humane values like respect, being peaceful, friendship and responsibility are statistically meaningful predictors of cyberbullying sensibility. Besides it was seen that honesty and being peaceful are significant predictors of cyberbullying.

Discussion and Conclusion. Rise in adolescents' level of humane values has an important role in increasing sensitivity against cyberbullying. In this sense, a decrease can be observed in also the tendencies to cyberbullying of the adolescents whose sensitivity has increased. On the other hand the result shows that a rise in adolescents' values of being peaceful will increase their tendencies of cyberbullying sensibility. It is estimated that a rise in adolescents' values of friendship and responsibility will increase their cyberbullying sensibility.
\end{abstract}

Keywords: Cyber-Bullying, Humane Values, Cyber-Bullying Sensibility, Structural Equivalence Modeling

Reception: 11.11.14 Initial acceptance: 12.20.14 Final acceptance: 03.02.16 


\section{Relaciones predictivas entre los valores humanos de los adolescentes, el acoso cibernético y la sensibilidad al acoso cibernético Resumen}

Introducción. El acoso cibernético ha sido más común que el acoso tradicional en los últimos años. Al igual que con el bullying tradicional, los valores humanos pueden explicar la razón por la que los adolescentes tienden a intimidar a través de cyber-medios. Los comportamientos de Cyber-bullying también son razonados por la sensibilidad de los adolescentes hacia ello. Este estudio investiga las relaciones predictivas entre los valores humanos de los adolescentes, el acoso cibernético y la sensibilidad al acoso cibernético.

Método. El estudio consistió en un total de 1743 participantes de diferentes escuelas secundarias en Estambul, Konya, Mersin, Ordu y Bursa (Turquía). 963 de los participantes eran mujeres y 780 eran varones. El grupo de estudio fue seleccionado entre los adolescentes que estudian en las escuelas secundarias mencionadas anteriormente por un método de muestreo aleatorio por conglomerados. El estudio empleó una Escala de Valores Humanos, una Escala Cyberbullying y la Escala sensibilidad al ciberacoso. Las relaciones predictivas entre los valores humanos de los adolescentes, el acoso cibernético y el acoso cibernético de sensibilidad se analizaron con un Modelo de Equivalencia Estructural, utilizando el programa informático AMOS 19.

Resultados. Los resultados del estudio revelaron que cada uno de los valores humanos como el respeto, ser pacífico, la amistad y la responsabilidad son estadísticamente predictores significativos de la sensibilidad al ciberacoso. Además, se observó que la honestidad y ser pacífico son predictores significativos de acoso cibernético.

Discusión y conclusión. El aumento en el nivel de los valores humanos de los adolescentes tiene un papel importante en el aumento de la sensibilidad contra el acoso cibernético. En este sentido, puede observarse una disminución en las tendencias al cyberbullying de los adolescentes cuya sensibilidad ha aumentado. Por otro lado, el resultado muestra que un aumento en los adolescentes con valores a ser pacíficos aumentará sus tendencias del cyberbullying de sensibilidad. Se estima que un aumento de los adolescentes en los valores de amistad y responsabilidad aumentarán su sensibilidad al problema del ciberacoso.

Palabras clave: Ciberacoso, valores humanos, Ciberacoso sensibilidad, Modelado de Equivalencia Estructural.

Recibido: 11/11/14 Aceptación Inicial: 20/12/14 Aceptación final: 03/02/16 


\section{Introduction}

Due to the intangible and perceptive nature of the concept, it is difficult for the term 'value' to possess a common definition accepted by majority. One will come across with different definitions of the concept when performing a literature review. Kohlberg (1981) interpreted the concept of 'value' as judging and acting with moral perceptions. While Hill (1991, defines the term as the beliefs held by individuals to which they attach special priority or worth, and by which they tend to order their lives. Veugelers (2000) comments on the term as values are constructs, that people can make choices, and that in making choices they reason and think about what to do and what to believe. Values are desirable trans situational goals, varying in importance, that serve as guiding principles in the life of a person or other social entity (Schwartz, 1994). Because the term 'value' is present in many different fields and different theorists associate the term with different concepts, it is difficult to set a common definition fort he term (Dilmaç, 2007; Dilmaç, Kulaksızoğlu and Ekşi, 2007). In the early 1990s, official bodies such as the School Curriculum and Assessment Authority (SCAA) used 'values' as a key term in their attempts to define spirituality and morality: 'values are the principles that inform judgments as to what is morally good or bad' (SCAA, 1996, p. 10).

According to Warnock (1996), values are either adopted or refused by the society or individual. The term 'values' in the literature (e.g., Kluckhohn, 1951 ; Kluckhohn \& Strobeck, 1961; Hofstede, 1980; 2001; Schwartz, 2006), can be defined as the beliefs that are held individually or collectively, perceived consciously or unconsciously, communicated explicitly (verbally articulately) or implicitly (symbolically), used as the criteria for cognitive, affective, or behavioral judgments to guide our choices out of available options, as they influence society, while society influences them (Shearman 2008). Morrow (1989) approached the concept of value from a different perspective and argued to mention rules and principles along with the term. He thinks values have the same meaning with rules and principles in the society When the definitions which handle over values in the view of an individual are examined perspective, Halstead and Taylor (1996) defines values as convictions and principles guiding our behaviors; standards used to decide whether certain behaviors are righteous or wrongful. Thomas (1992) on the other hand, defined the values as, thoughts accepted as beliefs by the individuals but not verified by the society. Values are important factors guiding the ways of 
our lives and how to organize them. As we have mentioned earlier, values are the choices of individuals and individuals make up the society, which in turn means that just as priorities become values of individuals, they become values of the society. Furthermore, values are more than just simple beliefs. Because believing in a value also means to comply with the behaviors in accordance with the value. However, setting this connection is not so easy. One must adapt to the environment while acting according to a certain value. Just as Pring (1984) stated, society must be suitable for a certain behavior to be exhibited. When an individual's behavior does not comply with the norms of the society, unpleasant situations and formations contradicting with the structure of the society are likely to occur. De la Fuente, Peralta and Sánchez (2006) stated interdependency relationships between social values and social maladjustment. Such inevitable formations trigger people's aggressive impulses and as a result, bear victims to such aggressions.

Aggression has been a major problem among all domains of life and throughout the history of mankind, from the primitive communities to the most civilized societies. However, it has been even more prominent, extensive and intense lately (Gökler, 2009). Aggression, with a general definition, can be considered as abrupt and damaging physical intervention on another person. Although bullying is a concept within the concept of aggression, a behaviour featuring just aggression can not be called 'bullying'. Bullying is usually defined [e.g., Olweus, 1999, Figure 1.1] as "a systematic abuse of power" subset of aggressive behavior characterized by repetition and an imbalance of power. The definition Facilities brought by the technology and the wide use of it by adolescents, enabled them to bully via the technology, which extended the traditional bullying concept and brought out a new concept of cyberbullying (Ayas and Horzum, 2010). Cyber-bullying can be defined as; facilitation of ongoing and deliberate harassment and threatening of an individual or a group of people intentionally by sending rude texts or views, deliberate, repetitive and hostile acts with intention to give harm to an individual or a group of people, involving the use of information and communication technologies like e-mails, cellular phones, pagers, sms services, and web-sites (Arıcak, 2009; Ang and Goh, 2010; Belsey, 2008; Berson, Berson and Ferron, 2002; Finkelhor, Mitchell and Wolak, 2008; Mason, 2008; Patchin and Hinduja, 2006; Willard, 2007; Ybarra and Mitchell, 2004a, 2004b; Totan, 2007; Wright \& di

Studies (Patchin and Hinduja, 2006; Slonje and Smith, 2008) revealed that adolescents intensely use information and communication Technologies including cellular phones, computers, internet, Olweus‘a (1999) according violence, as a person's physical or another 
individual using an objective can be considered a serious injury or harm is satisfactorily. PDA's. Websites intended for communication (blogs, social networks, video and Picture sharing websites) are also common among adolescents (Subrahmanyam and Greenfield, 2008). Communication with friends and relatives and access to any required information via internet are good aspects.

As with other social environments, however, the potential to meet and interact with others in possibly harmful ways exists (Ybarra, Diener-West and Leaf, 2007). Valkenburg and Soeters (2011), counted increase in the possibility of comig across with pornographic displays and violent materials, disclosure of personal information to others via information and communication technologies means and come to contact with those others in real life. Vandebosch and Van Cleemput (2008) looked at the number of times that certain negative aspects associated with the Internet and with mobile phones were mentioned during a study on the youngsters and had a rough idea about the problems and dangers that most concerned the youngsters. They found those (in order of diminishing frequency) being contacted by strangers (mentioned 52 times), computer viruses (49), hacking (38), pedophilic attempts (22), cyberbullying (20), threats (17), spam (17), stalking (14), e-advertising (14), sexual intimidation (12), pornographic Web sites (11), people who turn on their webcam unwanted (10), the cost of the communication (10), technical failure (10), health-related problems (5), and the content of certain Web sites (3). Scaglione and Scaglione (2006) reported that transfer of traditional bullying to the virtual environment is the major negative effect and is called cyber-bullying. Patchin and Hinduja (2006), states that individuals can hide behind some measure of anonymity when using their personal computer or cellular phone to bully another individual, which perhaps frees them from normative and social constraints on their behavior.

Researches reveal that cyber-bullying has serious impacts on school life. Beran and Li (2007) found that the school scores of cyber-victims fall suddenly, Raskauskas and Stoltz (2007) found that they avoid attending classes and Varjas, Heinrich and Meyers (2009) found that they do not percieve school as a secure place. Abrupt score drops of cyber-victims at school may be the result of lack of concentration and feeling excluded and helpless (Patchin and Hinduja, 2006). One of the important findings on the effects of cyber-bullying on school performance is revealed by the study of Ybarra, Diener-West and Leaf (2007). They found relation between being subject of intense cyber-bullying and truancy, school dropouts, bringing guns to school and being arrested. Adolescents should stay away from such stimuli in order not to be a subject of such treatments. And this requires them to be sensitive. Sensitivity 
can be expressed as keeping away from threatening stimuli and avoid coming across with them (Bayezid, 2000). Threats, which cause sensitivity can either be physical danger situations or prohibited urges, or just related to prevent from dysphoric feelings. Sensitizers have low arousal threshold against threats. Sensitizers, are extremely vigilant with regard to threatening situations or stimuli. Such individuals constantly scan the environment for potentially threatening stimuli, seeking to identify them and to respond to them in a way that minimizes their capacity for doing harm (Budd, Clopton, 1985).

\section{Aims and hypotheses}

In this context, susceptibility towards cyber-bullying can be defined as 'avoiding behaviors which may cause to become a victim of misuse of cyber devices such as internet and cellular phones, being aware of the fact that these such threats are possible, and taking measures against them, keeping high attention to notice such threats'. (Tanrıkulu, Kınay, and Arıcak, 2011). Susceptibility towards cyber-bullying should be investigated with both experimental and relational investigations (Tanrikulu, Kınay, and Arıcak, 2011). The purpose of this experiment in this context is to find out the predictive relationships between humane values of adolescents, cyber-bullying and susceptibility towards cyber-bullying.

In accordance with the aim of the research, below hypotheses will be tested:

1. Each of the sub-dimensions of the Humane Values Scale has an effect on cyberbullying sensibility.

2. Each of the sub-dimensions of the Humane Values Scale has an effect on cyberbullying.

3. Cyberbullying sensibility has an effect on cyberbullying.

\section{Method}

\section{Participants}

Participants in this study consisted of students who studied at different secondary schools. There were a total of 1743, 963 female (55\%) and $780(45 \%)$ male. The study group was selected among adolescents studying at the above mentioned secondary schools by random 


\section{Instruments}

Humane Values Scale (Dilmaç, 2007). HVS In the scale, humane values process was measured by 42 items in six different dimensions consisting of a. Responsibility ( 7 items), b. Friendship (7 items), c. amiability (7 items), d. Respect (7 items), e. Tolerance (7 items), f. Honesty (7 items). The scale was a Likert-type scale which could be applied individually or as a group. The responses for each item were stated in a five-point grading system (A: Never, B: Seldom, C: Sometimes, D: Often, E: Always). The items were graded as A: 1, B: 2, C: 3, D: 4 and E: 5. The higher scores one received indicated that the higher levels of humane values he/she had. Internal reliability coefficient (Cronbach Alpha) was used to determine the reliability in IDO. The alpha coefficients for the aforementioned sub-scales were calculated to be $.73, .69, .65, .67, .70$, and .69 , respectively. The overall internal reliability coefficient for the 42-item scale was found alpha .92. The stability factor was found .,73 for Responsibility, ,.91 for Friendship, .,80 for Pacifism, .,88 for Respect, .,79 for Tolerance and .,75 for Honesty. The stability coefficient for the whole scale was found to be, .87 .

Cyberbullying Scale (Arıcak, Kinay and Tanrıkulu, 2012). 24 items thought to reflect cyberbullying behaviors were determined. The study used explaratory factor analysis to determine construct validity of the scale, Cronbach Alpha analysis to calculate reliability coefficient and Spearman Rho correlation technique to find test-retest reliability coefficient. The single factor accounted for the $50.58 \%$ of the overall variance. The factor loads of the items under single factor ranged between .49- .80. The Cronbach alpha coefficient for the whole scale was calculated .95 while test-retest reliability coefficient was .70 . Consisting of 24 items, the scale is answered on a four-point scale (Never, Sometimes, Usually, Always). A response of "Never" was scored 1, "Sometimes" 2, "Usually" 3 and "Always" 4. The theoretical scores in the scale ranged between 24-96. A higher score in the scale represented higher levels of cyberbullying. There was no item requiring reverse scoring.

Cyberbullying Sensibility Scale (Tanrikulu, Kinay and Aricak, 2013). In order to determine adolescents' sensibility towards cyberbullying, Cyberbullying Sensibility Scale, developed by Tanrikulu, Kinay and Aricak (2013) has utilized. Consisting of 13 items, the scale was answered on a three point Likert type scale. (Yes, Sometimes, No). The scale was scored as 1 for a response of "No", 2 for "Sometimes" and 3 for "Yes". The lowest score that one 
could receive from the scale was 14 , while the highest score was 42 . The higher scores in the scale indicated higher levels of cyberbullying sensibility.

Based on the data collected, 15 items thought to reflect cyberbullying behaviors were determined. Exploratory factor analysis was used to test structure validity of the scale, Cronbach Alpha analysis to calculate internal reliability coefficient, and Pearson correlation techniques to find test-retest reliability coefficient. Moreover, confirmatory factor analysis of the scale was conducted in AMOS 19 program; the structure found in exploratory factor analysis was tested by confirmatory factor analysis. Taking into account the component matrix in the first analysis, all the items was found to cluster under a single factor except for the second one. For this reason, the factor analysis was repeated by extracting the second item and it was observed that all the items clustered under the first factor. This single factor accounted for $27.7 \%$ of the overall variance. The factor loads under a single factor ranged between .32- .73. The acquired single-factor structure was tested by confirmatory factor analysis, and the model was found to be appropriate at an acceptable level $\left(\chi^{2} / \mathrm{sd}=2.06\right.$ and $\left.\mathrm{RMSEA}=.078\right)$. The remaining 14 items in the scale significantly clustered under a single factor. The Cronbach alpha coefficient for the overall scale was calculated .79 while test-retest reliability coefficient was found to be .67 .

\section{Procedure}

Data collection of this research was carried out at a single session and took about 25 minutes. Researchers themselves delivered the questionnaires and voluntariness was taken into account as a priority in participating.

\section{Data Analysis}

In the present study, correlational survey design was used. Relational survey is conducted to determine the relationship between two or more variables and gain some insights about causal relations between them (Buyukozturk et.al., 2008). This study investigated the predictive correlations among humane values of adolescents, cyberbullying and cyberbullying sensibility.

In this study, the predictive correlations among humane values of adolescents, cyberbullying and cyberbullying sensibility were analyzed according to "Structural Equivalence Model" by using AMOS 19 program. The structural equivalence modeling is a statisti- 
cal approach which reveals the causal and mutual relationships between the observable and latent variables in order to test a theoretical model (Shumacker and Lomax, 2004). The suggested model related to the correlation between humane values and cyberbullying is given in the Figure 1.

\section{Results}

The model includes six exogenous (Tolerance, honesty, respect, peaceful, friendship and responsibility) and two endogenous variables (Cyberbullying Sensibility and Cyberbullying). All paths statistically significant in the model (Table 2).

The Bentler-Bonett normed fit index (NFI), The Tucker-Lewis coefficient fit index (TLI) and the other fit indices indicate that the model perfectly fit the date $\left(X^{2}=6.29, \mathrm{df}=6, \mathrm{p}\right.$ $=.39$ ). The correlations between all endogenous variables have moderate values and statistically significant. $(0.2<\mathrm{r}<0.5)$ The situation natural result of the humane values scale, include high relationship subscales, used in the model. Endogenous variables in this study are discussed in many studies about values and the endogenous variables showed a highly significant relationship to each other (Dilmaç, 2007; Dilmaç, Kulaksızoğlu and Ekşi, 2007; Schwartz and Boehnke, 2004; Schwartz, 1992). Only significant path are in the model.

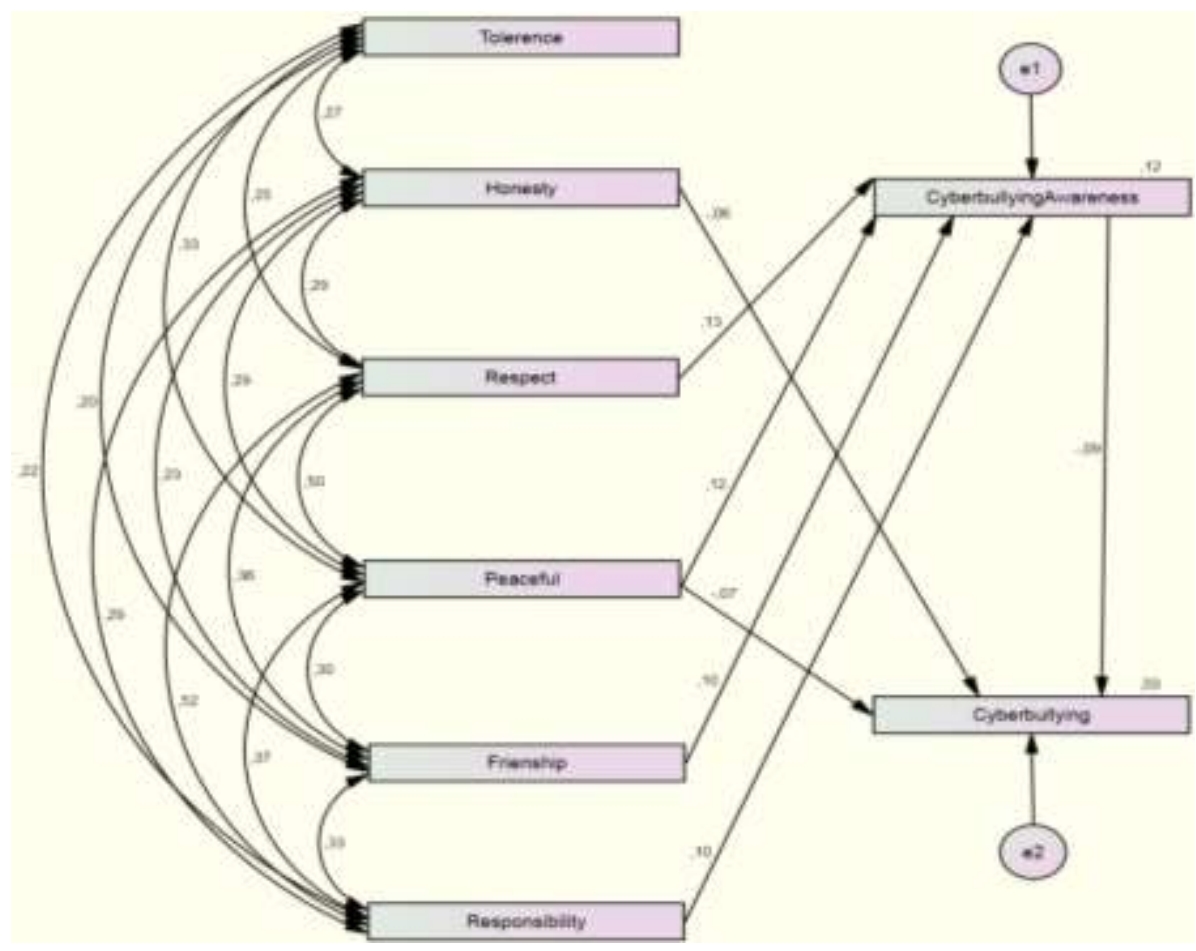

Figure 1. The related Model of predictive Relationships between Humane Values, Cyberbullying and Cyberbullying sensibility $(n=1743)$. 
Table 1. The Criterion References of the Related Structural Equation Model

\begin{tabular}{cccc}
\hline Criterion References & Perfect Fit Indices & Acceptable Fit Indices & The Model Indices \\
\hline$\left(\chi^{2} /\right.$ sd $)$ & $\leq 3$ & $\leq 4-5$ & 1,049 \\
RMSEA & $\leq 0,05$ & $0,06-0,08$ & 0,005 \\
NFI & $\geq 0,95$ & $0,94-0,90$ & 0,997 \\
CFI & $\geq 0,97$ & $\geq 0,95$ & 1,000 \\
GFI & $\geq 0,90$ & $0,89-0,85$ & 0,999 \\
AGFI & $\geq 0,90$ & $0,89-0,85$ & 0,995 \\
TLI & $\geq 0,95$ & $0,94-0,90$ & 0,999 \\
\hline
\end{tabular}

References: Hu and Bentler, 1999; Meydan and Şeşen, 2011.

Table 2 shows that the most effective variable on Cyberbullying Sensibility was re$\operatorname{spect}(t=4.61, p<.01)$. The coefficient value between Cyberbullying Sensibility and respect was $\beta=.43$. There was a positive and linear relationship between Cyberbullying Sensibility and respect. This finding suggested that an increase in adolescents' respect value would positively contribute to their Cyberbullying Sensibility.

Table 2. Decomposition of total effect for the Model of predictive Relationships between Humane Values, Cyberbullying and Cyberbullying sensibility

\begin{tabular}{llccccc}
\hline Predictor variable & Dependent variable & $\begin{array}{c}\text { Total effect } \\
\text { a }\end{array}$ & $\begin{array}{c}\text { Direct } \\
\text { effect }\end{array}$ & $\begin{array}{c}\text { Indirect } \\
\text { effect }\end{array}$ & $\begin{array}{c}\text { Standard } \\
\text { error }\end{array}$ & $\begin{array}{c}\text { Critical } \\
\text { ratio (t) }\end{array}$ \\
\hline Frienship & Cyberbullying Sensibility & 0,10 & 0,10 & 0 & 0,03 & $4,03^{* *}$ \\
\hline Respect & Cyberbullying Sensibility & 0,13 & 0,13 & 0 & 0,04 & $4,61^{* *}$ \\
\hline Responsibility & Cyberbullying Sensibility & 0,10 & 0,10 & 0 & 0,04 & $3,72^{* *}$ \\
\hline Peaceful & Cyberbullying Sensibility & 0,12 & 0,12 & 0 & 0,03 & $4,62^{* *}$ \\
\hline Honesty & Cyberbullying & $-0,06$ & $-0,06$ & 0 & 0,09 & $-2,47^{* *}$ \\
\hline Peaceful & Cyberbullying & $-0,09$ & $-0,08$ & $-0,01$ & 0,08 & $-2,93^{* *}$ \\
\hline Cyberbullying Sensibility & Cyberbullying & $-0,09$ & $-0,09$ & 0 & 0,06 & $-3,79^{*}$ \\
\hline
\end{tabular}

${ }^{\mathrm{a}}:$ Total effect $=$ Direct effect + Indirect effect, $* * p<.01, * p<.05$.

The second most effective variable on Cyberbullying Sensibility was Peaceful ( $t=4.61$, $p<.01)$. The coefficient value between Cyberbullying Sensibility and Peaceful was $\beta=.12$. There was a positive and linear relationship between Cyberbullying Sensibility and Peaceful. This finding also showed that an increase in adolescents' Peaceful value would positively contribute to their Cyberbullying Sensibility. The other independent variables that affected Cyberbullying Sensibility were Friendship and Responsibility $(t=4.03, p<.01 ; \mathrm{t}=3.72, p<.01)$. 
The value for each of the coefficients of these factors was found to be $\beta=.12$. The both variables showed a positive linear relationship between Cyberbullying Sensibility. It can be said that an increase in adolescents' Friendship and responsibility values would positively contribute to their Cyberbullying Sensibility.

The variables described above, respect, Peaceful, Friendship and responsibility values explained $12 \%$ of Cyberbullying Sensibility $\left(R^{2}=12\right)$. Thus, it was clear that respect, Peaceful, Friendship and responsibility values impact on Cyberbullying Sensibility.

In Table 2, the effective variables on Cyberbullying were Peaceful, Honesty values and Cyberbullying Sensibility $(t=-2.47, p<.01 ; t=-2.93, p<0.01 ; t=-3.79, p<.05)$. Connection for each of the coefficients of these factors were found to be $\beta=-, 06 ; \beta=-, 09 ; \beta=-, 09$. The both variables showed a negative linear relationship between Cyberbullying. This finding indicates that an increase in adolescents' Peaceful, Honesty values and Cyberbullying Sensibility would negatively contribute to their Cyberbullying. In Table 2, the indirect effect variables on Cyberbullying were Peaceful, Responsibility and Respect values. Connection for each of the coefficients of these factors was found to be $\beta=-, 01$. The both variables showed a negative linear relationship between Cyberbullying. This finding shows that an increase in adolescents' Responsibility, Respect and Peaceful values would negatively contribute to their Cyberbullying. Honesty, Responsibility, Peaceful values and Cyberbullying Sensibility had different level effect on Cyberbullying, explained $3 \%$ of Cyberbullying $\left(\mathrm{R}^{2}=3\right)$. Thus, it was clear that this variables impact on Cyberbullying.

\section{Discussion and Conclusions}

The result of the study revealed that each of the humane values like respect, being peaceful, friendship and responsibility are statistically meaningful predictors of cyberbullying sensibility to cyberbullying. Besides it was seen that honesty and being peaceful are significant predictors of cyberbullying. Increasing adolescents' values of honesty and being peaceful shows it will decrease their cyberbullying. In the literature a direct finding that is appropriate to the model of this research and in parallel with its findings could not be found. Although there are not direct findings, we are going to try to do the discussion in this part by giving indirect findings which we think are relevant to the study. The findings of the research that was carried out by Dilmaç and Aydogan (2010) in order to examine the relationship between the humane values and cyberbullying of secondary school students support the findings of this 
research. In research findings it is expressed that there is a relationship between secondary school students' values of responsibility, friendship, being peaceful, respect, tolerance, honesty and their cyberbullying. Besides, on their research conducted with high school students, Peker, Eroglu and Ada (2012) discovered significant relationships between emphatic tendency, cyberbullying and cybervictimization. They had reported a positive and significant relationship between cybervictimization and cyberbullying and a negative and significant relationship between emphatic tendencies, cyberbullying and cyberbullying sensibility.

In a research carried out by Dilmaç (2009) to find out the relationship between cyberbullying and personal characteristics, the ones who are not bully-victims have more persistent characteristic compared to self-victims and bully-victims. Persistency is the only variable that predicts cyberbullying. When the values of persistency rise, cyber victimization rate falls. Similarly, Rahey (2007) put forth that when the persistency between friends rises, physical victimization falls. Another similar finding in that research was that persistency predicts the possibility of involving in a cyberbullying in the future negatively. For this reason, it is stated that persistence is a negative psychological feature with respect to cyberbullying. Another research finding revealed by Dilmaç (2009) is that the ones who are not bully-victims indicate that they have less affiliation features than bully-victims. Affiliation predicts the possibility of cyber victimization (victimhood) and involving in a cyberbullying in the future. Pellegrini and Bartini (2002) state that social affiliation prevents victimhood. The findings of our research supports this statement. Another finding of the research is Humane Values Scale's sub-dimension of being peaceful also predicts cyberbullying. Existing literature shows that there is a strong relationship between aggression and cyberbullying (Beran and Li, 2005; Chisholm, 2006; David-Ferdon and Hertz, 2007; Harman et al., 2005; Yaman, Karakilah and Dilmaç, 2012; Willard, 2007). In his research Dilmaç (2009) ascertained that aggression predicts both involving in cyberbullying (as bully) and the possibility of involving in cyberbullying in the future. As can be seen, these findings support the findings of our research.

According to Cunningham (2007), Haynie et al. (2001) and Pellegrini, Bartini and Brooks (1999) bullies, victims and bully-victims have different psychological and social characteristics from each other. Adolescent bullies generally tend to be very emotional and their self-control is low. It was observed that bullies display both proactive and reactive aggressive behaviors and they use proactive aggression to establish supremacy and to be leader in peer groups (Barco, Castaño, Carroza, and Ramos, 2011; Juvonen, Graham and Shuster, 2003; 
McKenney, Pepler, Craig and Connolly, 2006; Pellegrini, Bartini and Brooks, 1999). Yaman and Peker (2012) determined that cyberbullying behavior exhibited by students are categorized as cyber verbal language, cyberforgery, and hiding identity. According to the results of their study, Yaman and Peker (2012) indicated that the reasons for cyberbullying include gaining social popularity, struggling boredom, and making revenge. The findings of this study indicated that students maintain cyberbullying to feel well, empower friendships, and enjoy their time and that students feel anger, sadness, and revenge when they experience cybervictimization.

In Patchin and Hinduja's study, nearly 30 percent of the adolescents expressed that they became a victim of cyberbullying by being ignored, not being respected, nicknaming, threatening, teasing, scoffing or spreading gossip (Patchin and Hinduja, 2006). When it is asked to cyber-victims how they felt themselves after exposure to bullying, one of the victims stated that s/he had felt angry, sad, depressed, hurt, stressed and frustrated and the other one said s/he had been weak, insulted, so lonely and helpless (Kowalski and Witte, 2006). As well as low academic performance, psychological effects such as depression, loneliness, weakness in social relationships, low self-esteem, sadness, anger, fear, anxiety and paranoid thoughts are seen in individuals living such kinds of negative feelings (Benan and Li, 2005, Hawker and Boulton, 2000, Nishina, Juvonen and Witkow, 2005). Rise in adolescents' level of humane values has an important role in increasing sensitivity against cyberbullying. In this sense, a decrease can be observed in also the tendencies to cyberbullying of the adolescents whose sensitivity has increased. The discussion of the finding will be done between themselves because no research finding could be found about the cyberbullying sensitivity in the literature.

A positive and linear relationship was found between the respect values of adolescents and their cyberbullying sensibility. In other words, this result presents that adolescents' tendencies of cyberbullying sensibility will increase when their respect values rises. A positive and linear relationship was discovered between adolescents' values of being peaceful and their cyberbullying sensibility. In other words, this result shows that a rise in adolescents' values of being peaceful will increase their tendencies of cyberbullying sensibility. It is estimated that a rise in adolescents' values of friendship and responsibility will increase their cyberbullying sensibility. It is seen that values that effect the cyberbullying sensibility at different levels such as respect, being peaceful, friendship and responsibility explain twelve percent of the cyberbullying sensibility $\left(\mathrm{R}^{2}=0,12\right)$. These findings show that each value like re- 
spect, being peaceful, friendship and responsibility is an important explicator of the cyberbullying sensibility. It is seen that adolescents' cyberbullying sensibility increases as their value levels rise, which means their tendencies to cyberbullying decrease.

\section{References}

Ang, R. P., \& Goh, D. H. (2010). Cyberbullying among adolescents: the role of affective and cognitive empathy, and gender. Child Psychiatry \& Human Development, 41(4), 387397. doi:10.1007/s10578-010-0176-3

Arıcak, O. T. (2009). Psychiatric symptomatology as a predictor of cyberbullying among university students, Eurasian Journal of Educational Research, 34, 167-184.

Arıcak, O. T., Kınay, H., \& Tanrıkulu, T. (2012). Siber zorbalık ölçeği'nin ilk psikometrik bulguları. Hasan Âli Yücel Eğitim Fakültesi Dergisi, 9(1), 101-114.

Arıcak, T., Siyahhan, S., Uzunhasanoglu, A., Sarıbeyo glu, S., Çıplak, S., Yılmaz, N., et al. (2008). Cyberbullying among Turkish adolescents. CyberPsychology \& Behavior, $11(3), 253-261$.

Ayas T., Horzum M. B. (2010), Sanal Zorba / Kurban Ölçek Geliştirme Çalışması, Akademik Bakış Dergisi, sayı 19, 1-1.

Bayezid, G. (2000), Bastırma duyarlılık ölçeğini türk kültürüne uyarlama çalışması. Düşünen Adam, 13(2), 99-106.

Belsey, B. (2008). Cyberbullying. Retrieved August 03, 2008, from, http://www.Cyberbullying.org. 16.12.2011 tarihinde alınmıştır.

Beran, T., \& Li, Q. (2005). Cyber-harassment: A study of a new method for an old behavior. Journal of Educational Computing Research, 32(3), 265-277.

Berson, I. R., Berson, M. J., \& Ferron, J. M. (2002). Emerging risks of violence in the digital age: Lessons for educators from online study of adolescent girls in the United States. Journal of School Violence, 1(2), 51-71.

Büyüköztürk, Ş., K1lıç-Çakmak, E., Akgün, Ö. E., Karadeniz, Ş. \& Demirel, F. (2008). Bi limsel araştırma yöntemleri. Ankara: Pegem Yayıncılık.

Chisholm, J. F. (2006). Cyberspace violence against girls and adolescent females. Annals of the New York Academy of Sciences, 1087(1), 74-89.

Cunningham, N. J. (2007). Level of bonding to school and perception of the school environment by bullies, victims, and bully victims. Journal of Early Adolescence, 27(4), 457478. 
David-Ferdon, C., \& Hertz, M. F. (2007). Electronic media, violence, and adolescents: An emerging public health problem. Journal of Adolescent Health, 41, 1-5.

de la Fuente, J., Peralta, J., \& Sánchez, M. D. (2006). Sociopersonal values and coexistence problems in secondary education. Electronic Journal of Research in Educational Psychology, 4(2), 171-200.

del Barco, B. L., Castaño, E. F., Carroza, T. G., \& Ramos, V. L. (2011). Acoso escolar en la Comunidad de Extremadura vs. Informe español del Defensor del Pueblo (2006). Electronic Journal of Research in Educational Psychology, 9(24), 565-586.

Dilmaç, B, Kulaksızoğlu, A., \& ve Ekşi H. (2007). An examination of the humane values education program on a group of science high school students Educational Sciences: Theory \& Practice,. Cilt 7, Sayl 3, 1221-1261.

Dilmaç, B. \& Aydoğan, D. (2010). Values as a predictor of cyber-bullying among secondary school students. International Journal of Human and Social Sciences, 5(3), 185-188.

Dilmaç, B. (2009). Psychological needs as a predictor of cyber-bullying: a preliminary report on college students Educational Sciences: Theory \& Practice, 9(3),1291-1325.

Dilmaç. B. (2007). Bir grup fen lisesi ögrencisine verilen insani dĕgerler eğitiminin insani değerler ölçeği ile sınanması. (doktora tezi, , Selçuk Üniversitesi, Sosyal Bilimler Enstitüsü, Konya). http://tez..yok.gov.tr/ adresinden alınmıştır.

Mitchell, K. J., Finkelhor, D., Wolak, J., Ybarra, M. L., \& Turner, H. (2011). Youth internet victimization in a broader victimization context. Journal of Adolescent Health, 48(2), $128-134$.

Gökler R. (2009), Okullarda akran zorbalığı, Uluslar arası Insan Bilimleri Dergisi Cilt 6(2) 511-537.

Halstead J \& Taylor M (eds) (1996). Values in education and education in values. London: Falmer Press: Harper and Row.

Harman, J. P., Hansen, C. E., Cochran, M. E., \& Lindsey, C. R. (2005). Internet faking but not frequency of use aff ects social skills, self-esteem, social anxiety, and aggression. CyberPsychology \& Behavior, 8(1), 1-6.

Hawker, D. S. J. \& Boulton, M. J. (2000). Twenty years' research on peer victimization and psychosocial maladjustment: A meta-analytic review of crosssectional studies. Journal of Child Psychology and Psychiatry, 41, 441-455.

Haynie, D. L., Nansel, T., Eitel, P., Crump, A. D., Saylor, K., Yu, K., \& Simons- Morton, B. et al. (2001). Bullies, victims, and bully victims: Distinct groups of at-risk youth. Journal of Early Adolescence, 21(1), 29-50. 
Hill B.V. (1991). Values Education in Australian Schools. Melbourne: ACER.

Hu, L. T., \& Bentler, P. M. (1999). Cutoff criteria for fit indexes in covariance structure analysis: Conventional criteria versus new alternatives. Structural equation modeling: $a$ multidisciplinary journal, 6(1), 1-55.

Juvonen, J., Graham, S., \& Shuster, M. A. (2003). Bullying among young adolescents: The strong, the weak, and the troubled. Pediatrics, 112(6), 1231-1237.

Kohlberg, L. (1981). Essays on moral development. Vol. 1, The philosophy of moral development: moral stages and the idea of justice. Harper \& Row.

Kowalski, R.M., \& Witte, J. (2006). Youth internet survey. Available: http://www.camss.clemson.edu/KowalskiSurvey/servelet/Page1_adresinden 12.07.2009 tarihinde ulaşılmıştır.

Mason, K. L. (2008). Cyberbullying: A preliminary assessment for school personnel. Psychology in the Schools, 45(4), 323-348.

McKenney, K. S., Pepler, D., Craig, W., \& Connolly, J. (2006). Peer victimization and psychosocial adjustment: The experiences of Canadian immigrant youth. Electronic Journal of Research in Educational Psychology, 9(4), 239-264.

Meydan, C. H., \& Şeşen, H. (2011). yapısal eşitlik modellemesi amos uygulamaları. Ankara: Detay Yayıncılik

Morrow W (1989). Chains of Thought. Johannesburg: Southern Book Publishers.

Nesbitt, E.,Henderson, A. (2003). Religious Organisations in the UK and values education programmes for Schools. Journal of Beliefs \& Values, 24(1), 75-88.

Nishina, A., Juvonen, J., \& Witkow, M.R. (2005). Sticks and stones may break my bones, but names will make me feel sick: The psychosocial, somatic, and scholastic consequenc es of peer harassment. Journal of Clinical Child and Adolescent Psychology, 34(1), $37-48$.

Olweus, D. (1999). Norway. In P. K. Smith, Y. Morita, J. Junger-Tas, D. Olweus, R. Catalano \& P. Slee (Eds.), The nature of school bullying: A cross-national perspective (pp. 28 48). London and New York: Routledge.

Patchin, J. W., \& Hinduja, S. (2006). Bullies move beyond the schoolyard: A preliminary look at Cyberbullying. Youth Violence and Juvenile Justice, 4(2), 148-169.

Peker, A., Eroğlu, Y., \& Ada, Ş. (2012). Ergenlerde Siber Zorbalığın Ve Mağduriyetin Yordayıcılarının İncelenmesi. Abant İzzet Baysal Üniversitesi Eğitim Fakültesi Dergisi, 12(2), 185-206 
Pellegrini, A. D., Bartini, J. D. (2002). A longitudinal study of bullying, dominance, and victimization during the transition from primary school through secondary school. British Journal of Developmental Psychology, 20, 259-280.

Pellegrini, A. D., Bartini, M., \& Brooks, F. (1999). School bullies, victims, and aggressive victims: Factors relating to group aff iliation and victimization in early adolescence. Journal of Educational Psychology, 91(2), 216-224.

Pring, R. (1984) Personal and Social Education in the Curriculum. London: Hodder and Stoughton.

Rahey, L. A. (2007). Th e direct and moderating eff ect of bullying on adolescent health. Queen's University Kingston, Ontario, Canada. Retrieved August 13, 2008 from http://qspace.library.queensu.ca/handle/1974/447.

Raskauskas, J., \& Stoltz., A. D. (2007). Involvement in traditional and electronic bullying among adolescents. Developmental Psychology, 43(3), 564-575.

Scaglione, J., \& Scaglione, A. R. (2006). Bully-proofing childen: a practical, hands on guide to stop bullying, Rowman \&Littlefield Education: United States of America.

Schumacker, R. E. And Lomax, R. G. (2004). A beginners's guide to structural equaiton modeling. London: Lawrence Erlbaum Associates, Publishers.

Schwartz, S.H. (1994). Are there universal aspects in the structure and content of human values? Journal of Social Issues 50 (4), 19-45.

Schwartz, S.H. and Boehnke, K. (2004). Evaluating the structure of human values with con firmatory factor analysis. Journal of Research in Personality, 38, 230-255.

Schwartz, S.H.(1992). Universals in the Content Structure of Values: Theoretical Advances and Empirical Tests in 20 Countries. In Zanna (Ed.), Advances in Experimental Social Psychology (Vol. 25, pp. 1-65). New York: Academic Pres.

Shearman, S.M.(2008). Culture, values, and cultural variability: Hofstede, inglehart, and Schwartz's approach. The Annual Convention of the International Communication Association, Montreal, QC, Canada.

Slonje, R., \& Smith P. K. (2008). Cyberbullying: Another main type of bullying? Scandinavi an Journal of Psychology, 49, 147-154.

Subrahmanyam, K., \& Greenfield, P. (2008). Online communication and adolescent relationships. The Future of Children, 18(1), 119-146.

Survey. Juvenile Justice Fact Sheet-FS200104. Washington, DC: US Government Printing Office 2001. Retrieved August 3, 2008, from http://www.unh.edu/ccrc/ $\mathrm{pdf} / \mathrm{jvq} / \mathrm{CV} 46 . \mathrm{pdf}$. 
Tanrıkulu, T. (2011). Siber Zorbalık Duyarlılığ $\quad$ Nedir? http://www.siberzorbalik.com/?page_id=66.

Tanrıkulu, T., Kınay, H. ve Arıcak, O.T. (2011). Siber zorbalı̆̆a ilişkin duyarlılık ölçeği. İzmir: XI.Ulusal Psikolojik Danışma ve Rehberlik Kongresi Bildiri Özetleri Kitabı, 338-339.

Tanrıkulu, T., Kınay, H., \& Arıcak, O. T.(2013). Siber Zorbalığa İlişkin Duyarlılık Ölçeği: Geçerlik ve Güvenirlik Çalışması. Trakya Üniversitesi Ĕ̌itim Fakültesi Dergisi, 3(1), $38-47$

Thomas, R. S.(1992). Values Education Discourse: A Classification of Exemplars (Doctoral dissertation) Available from ProQuest Dissrtations and Theses database., (UMI: 9315734 )

Totan, T. (2007), Okulda Zorbalı̆̆ Önlemede Eğitimcilere Ve Ebeveynlere Öneriler. $A \dot{I} B \ddot{U}$, Eğitim Fakültesi Dergisi, 7(2),190-202

Valkenburg, P. M., \& Soeters, K. (2001). Children's positive and negative experiences with the Internet: An exploratory survey study. Communication Research, 28, 653-676.

Vandebosch, H., Van Cleemput, K.(2008). Defining Cyberbullying: A Qualitative Research into the Perceptions of Youngsters. CyberPsychology \& Behavior, 11(4), 499-503.

Varjas, K., Henrich, C. \& Meyers, J. (2009). Urban middle school students' perceptions of bullying, Cyberbullying and school safety. Journal of School Violence, 8, 159-176

Veugelers W (2000). Different ways of teaching values. Educational Review, 52:37-45.

Warnock, M. (1996). The Nature of Values. J.Mark Halstead and Monica J.Taylor (Ed.), Values in Education and Education in Values (s.46). London: Washington, D.C.

Willard, N. (2007). Educator's guide to Cyberbullying and cyberthreats 2007. Retrieved August 3, 2008, from http://www.cyberbully.org/cyberbully/docs/cbcteducator. pdf.

Wright, V. H., Joy J. B., Christopher T. Inman, \& Heather N. O. (2009), Cyberbullying: Using Virtual Scenarios to Educate and Raise Awareness. Journal of Computing in Teacher Education, 26(1), 35-42.

Yaman, E., \& Peker, A. (2012). Ergenlerin siber zorbalık ve siber mağduriyete ilişkin algıları. University of Gaziantep Journal of Social Sciences, 11(3), 819-833.

Yaman, E., Karakülah, D., \& Dilmaç, B(2013). . İlköğretim ikinci kademe öğrencilerinin değerlerini yordayan iki önemli değişken: siber zorbalık eğilimleri ve okul kültürü arasındaki ilişki, Değerler Ĕgitimi Dergisi, 11(26), 323-337. 
Ybarra, M., \& Mitchell, K. J. (2004a ). Online aggressor/targets, aggressors, and targets: A comparison of associated youth characteristics. Journal of Child Psychology and Psychiatry, 45(7), 1308-1316.

Ybarra, M. L., Diener-West, M., \& Leaf, P. J. (2007). Examining the overlap in internet harassment and school bullying: Implications for school intervention. Journal of Adolescent Health, 41, 42-50.

Ybarra, M., \& Mitchell, K. J. (2004b). Youth engaging in online harassment: associations with caregiver-child relationships, Internet use, and personal characteristics. Journal of Adolescence, 27, 319-336. 